\title{
Rozpor mezi projektovou dokumentací a skutečným stavem vztaženo k problematice oceňování objektů
}

\author{
The Contrast Between Plans/Drawings and the Actual State in Relation \\ to the Issue of Property Valuation
}

Monika (Králíková) Ledvoňová*, Pavel Pejchal

STATIKUM s.r.o., Brno

\begin{abstract}
Abstrakt
Projektové dokumentace, at’ už se jedná o projektovou dokumentaci jakéhokoliv stupně, je velmi vítanou pomůckou př̀ získávání podkladů, potřebných pro výpočet zastavěné plochy a obestavěného prostoru při oceňování objektů. Během výstavby a během životnosti staveb pak dochází $\mathrm{k}$ řadě změn, které se často již do projektů, podle kterých je stavba prováděna a následně do projektu skutečného provedení stavby nepromítnou, a tak může dojít k značným odchylkám mezi stavem, který je zanesen v projektové dokumentaci a stavem, který je skutečně realizován. Tento článek v první části nastiňuje problematiku různých stupňủ projektových dokumentací včetně nutnosti nebo jen př́padné možnosti jejich opatření razítkem autorizované osoby a v dalš́ části poukazuje na zjištěné, zcela fatální, rozdíly mezi předloženou projektovou dokumentací a skutečně realizovaným stavem. Př́spěvek byl prezentován na konferenci ExFoS 2019 ve dnech 24.-25. ledna 2019.
\end{abstract}

Klíčová slova: projektová dokumentace, autorizovaný inženýr, životnost staveb, odchylka, realizovaný stav, oceňováni nemovitých věcí.

\section{1. ÚVOD}

Při oceňování nemovitostí se znalec setkává s různými druhy projektových dokumentací, ze kterých následně čerpá informace o objektu, jenž je předmět ocenění. Pro získání co nejrelevantnějších informací je vhodné získat od majitele objektu projektovou dokumentaci skutečného provedení stavby, kterou má majitel objektu dle stavebního zákona [1] povinnost uchovávat po celou dobu životnosti stavby. I když vlastník objektu tuto projektovou dokumentaci předloží, ani v takovém př́ípadě není možno zcela spoléhat na to, že dokumentace realizovanému stavu skutečně

\begin{abstract}
Plans/drawings, no matter of what degree, are a very much appreciated tool in gaining materials necessary for the calculation of built-up area and built-in space in property valuation. During the construction and life span of buildings, several changes occur that are not reflected in the plans on which the construction is based, and later such changes are not considered in the actual construction of the building, hence the considerable deviation of the state recorded in plans/drawings and the actual construction.
\end{abstract}

This article, in its first part, outlines the issue of various degrees of plans/ drawings, including the need or possibly only the option to be equipped with a stamp by an authorized person. Further, the article demonstrates the detected, utmost differences between the submitted plans/drawings and the actual construction. The paper was presented at the ExFoS 2019 conference, $24-25^{\text {th }}$ January.

Keywords: plans/drawings, authorized person, life span of buildings, changes, the actual construction, real estate valuation. odpovídá. Daleko větší nepřesnost pak může být do ocenění vnesena $\mathrm{v}$ tom prŕípadě, dojde-li k získání informací z projektové dokumentace ke stavebnímu povolení či dokonce z projektové dokumentace k územnímu rozhodnutí, kdy během realizace dochází $\mathrm{k}$ více či méně podstatným odchylkám od původně navrženého stavu.

Tento článek předkládá náležitosti, které musí obsahovat projektová dokumentace jednotlivých stupňů, jež je často znalci používána jako podklad při oceňování objektů a na praktických př́kladech poukazuje, že nejvěrohodnější informace o objektu se získávají jeho zaměřením a prohlídkou při místním šetření. 


\section{OBECNÁ PRAVIDLA PRO OPATŘENÍ RAZÍTKEM PROJEKTOVÉ DOKUMENTACE AUTORIZOVANÝMI OSOBAMI}

Vypracovaná projektová dokumentace pro vydání územního rozhodnutí a projektová dokumentace stavby pro vydání stavebního povolení, která se předkládá stavebnímu úřadu, spolu s projektovou dokumentací skutečného stavu jsou nejčastější podklady, se kterými se znalec při oceňování nemovitostí setkává. Zatímco první dvě musí být opatřeny razítkem autorizované osoby, třetí, která by měla odrážet zrealizovanou skutečnost, opatřená autorizačním razítkem být nemusí, ale musí být ověřena dle vydaných povolení.

S projektovou dokumentací pro provádění stavby, která má být podle informací uvedených níže $\mathrm{v}$ textu také opatřena razítkem autorizované osoby, se u stavby rodinných domů setkáváme v praxi velmi ojediněle. Pro stavbu jsou často použity výkresy, ověřené stavebním úřadem, na jejichž základě bylo získáno stavební povolení.

\subsection{Použití autorizačního razítka dle ČKAIT}

Veškeré informace o použití autorizačního razítka jsou uvedeny na webových stránkách ČKAIT v článku Pravidla pro používání razítka při výkonu povolání autorizovaného inženýra a autorizovaného technika, Rozhodnutí č. R1801-9 představenstva ČKAIT ze dne 15. 2. 2018 [2]. Přehled dokumentů, které autorizovaná osoba opatřuje autorizačním razítkem a vlastnoručním podpisem je uveden v článku 3, který je uveden dále v textu.

\section{„Článek 3}

1. Autorizovaná osoba musí opatřit svým vlastnoručním podpisem a autorizačním razitkem zejména:

a) územně plánovaci dokumentaci,

b) územni studii,

c) dokumentaci pro vydání územního rozhodnutí a pro uzavřeni veřejnoprávní smlouvy nahrazující územní rozhodnutí,

d) projektové dokumentace podle § 158 odst. 2 stavebniho zákona [1]. ${ }^{1)}$

e) potvrzení identifikačnich údajů ve stavebním deniku podle §157 SZ-jména a príjmení osob zabezpečujícich odborné vedení prováděni stavby (stavbyvedouci), autorský dozor projektanta a technický dozor stavebníka,

\footnotetext{
1) Zde je pro přehlednost uveden $\S 158$ (2) zákona č. 183/2006 Sb. Zákon o územním plánování a stavebním řádu (stavební zákon)

a) stavby podle $\$ 104$ odst. 1 písm. a) až e),

b) stavby pro vydáni stavebního povolení podle $\$ 115$,

c) k uzavřeni veřejnoprávní smlouvy podle $\$ 116$,

d) k posouzeni autorizovaným inspektorem podle $\$ 117$

e) stavby pro vydání společného povolení,

f) změn staveb uvedených v písmenech a) až e) před jejím dokončením podle $\S 118$,

g) staveb uvedených v písmenech a) ažf) k opakovanému stavebnímu řizeni nebo dodatečnému povoleni stavby podle $\$ 129$,

h) pro prováděni stavby,

i) pro nezbytné úpravy podle $\$ 137$, nebo

j) vodního díla $k$ ohlášení podle $\$ 15$ a odst. 1 vodního zákona [2].

Náležitosti projektové dokumentace jsou pak uvedeny ve vyhlášce

č. 499/2006 Sb. Vyhláška o dokumentaci staveb v aktuálním znění, zejména po aktualizaci z 1. 1. 2018
}

f) písemné prohlášeni stavbyvedoucího u staveb prováděných svépomoci, že povede prováděni stavby podle \$160 odst. $4 \mathrm{SZ}$,

g) dokumentaci pro uchazeče o autorizaci potvrzující jeho odbornou praxi.

2. Autorizovaná osoba musí opatřit vlastnoručním podpisem a autorizačním razitkem samostatné dílči části dokumentace, pokud spadaji pod bod 1. pism. a-d (např. jednotlivé specializace oboru a profesí, statický a dynamický výpočet, zprávu o průzkumu stavby, o zkoušení a diagnostice stavby).

3. Autorizovaná osoba můz̆e opatřit vlastnoručním podpisem a autorizačním razitkem dalši dokumenty a odborná vyjádřeni $v$ souvislosti s př́pravou a prováděním stavby, odborná stanoviska a posudky.

4. Počet paré jednoho dokumentu označených vlastním podpisem a autorizačnim razitkem je odvislý od potřeby v souvislosti s prípravou a provádèním stavby [2]. “

Výše v textu je kladen důraz na rozdíly, kdy autorizovaná osoba musí a kdy může dokumenty opatřovat vlastnoručním podpisem a autorizačním razítkem.

Dále je uvedeno, že autorizovaná osoba opatřuje podpisem a autorizačním razítkem pouze ty dokumenty, které vypracovala osobně, popřípadě ve spolupráci s dalšími osobami pracujícími pod jejím odborným vedením. Takto označené listiny jsou pro úřední účely veřejnými listinami.

\subsection{Vyhláška č. 499/2006 Sb. Vyhláška o dokumentaci staveb} v aktuálním znění

Informace o tom, jaké náležitosti musí dokumentace obsahovat, jsou uvedeny ve vyhlášce č. 499/2006 Sb. Vyhláška o dokumentaci staveb. V této vyhlášce je uveden rozsah a obsah následujících dokumentací:

„a) dokumentace pro vydání rozhodnutí o umistění stavby nebo zařizení (dále jen „stavba“),

b) dokumentace pro vydání rozhodnutí o změně využití území,

c) dokumentace pro vydání rozhodnutí o změně vlivu uživání stavby na území,

d) dokumentace pro vydání společného povolení,

e) projektové dokumentace pro ohlášeni stavby uvedené v § 104 odst. 1 písm. a) až e) stavebniho zákona nebo projektové dokumentace pro vydáni stavebního povoleni,

f) projektové dokumentace pro provádění stavby a

g) dokumentace skutečného provedení stavby.

(2) Tato vyhláška dále stanoví náležitosti dokumentace bouracích prací, obsahové náležitosti stavebniho deníku, jednoduchého záznamu o stavbě a způsob jejich vedení [3]. “

Z tohoto následně vyplývá, že např́ílad dokumentace skutečného provedení musí splňovat náležitosti dané vyhláškou č. 499/2006 Sb. Vyhláška o dokumentaci staveb, ale nemusí být opatřena autorizačním razítkem. Dokument, který uvádí skutečně zrealizovaný stav, může být tedy zakreslen prakticky kýmkoliv a následně je tuto dokumentaci, dle stavebního zákona [1], vlastník stavby povinen uchovávat po celou dobu trvání stavby. V zákoně je tato povinnost uvedena následovně: 


\section{„\$125 Dokumentace skutečného provedení stavby}

(1) Vlastnik stavby je povinen uchovávat po celou dobu trváni stavby ověrenou dokumentaci odpovídajici jejímu skutečnému provedeni podle vydaných povolení. V prípadech, kdy dokumentace stavby nebyla vůbec pořizena, nedochovala se nebo nenív náležitém stavu, je vlastnik stavby povinen pořídit dokumentaci skutečného provedeni stavby. Při změnè vlastnictví ke stavbě odevzdá dosavadni vlastnik dokumentaci novému vlastníkovi stavby. “

Obdobně se jedná o stejné povinnosti v $§ 154$, kde jsou uvedeny povinnosti vlastníka stavby a zařízení. Dále je ještě v témž odstavci uvedena povinnost uchovávat stavební deník po dobu 10 let od vydání kolaudačního souhlasu, popř́ípadě od dokončení stavby, pokud se kolaudační souhlas nevyžaduje.

Ze zkušeností z místních šetření prováděných pracovníky znaleckého ústavu bylo zjištěno, že často nejsou projektové dokumentace skutečného provedení ani zjednodušené pasporty stavby uchovávány vůbec nebo takto uchovávané dokumenty neodpovídají skutečnému provedení stavby.

Obdobné zjištění je také v prrípadě objektů mladších 10 let, kdy není možné vyzískat stavební deník nebo tento stavební deník byl veden vadně, nejčastěji chybí údaje o stavbyvedoucím - osobě oprávněné vést stavbu.

\section{UKÁZKY ODCHYLEK SKUTEČNÉHO STAVU OPROTI PROJEKTOVÉ DOKUMENTACI}

\subsection{Př́íklad č. 1}

V prŕíkladu č. 1 se jedná o rozestavěnou stavbu rodinného domu, kdy již ve fázi výstavby byly provedeny změny, které změnily mimo jiné hlavně tepelně technické vlastnosti rodinného domu jako celku
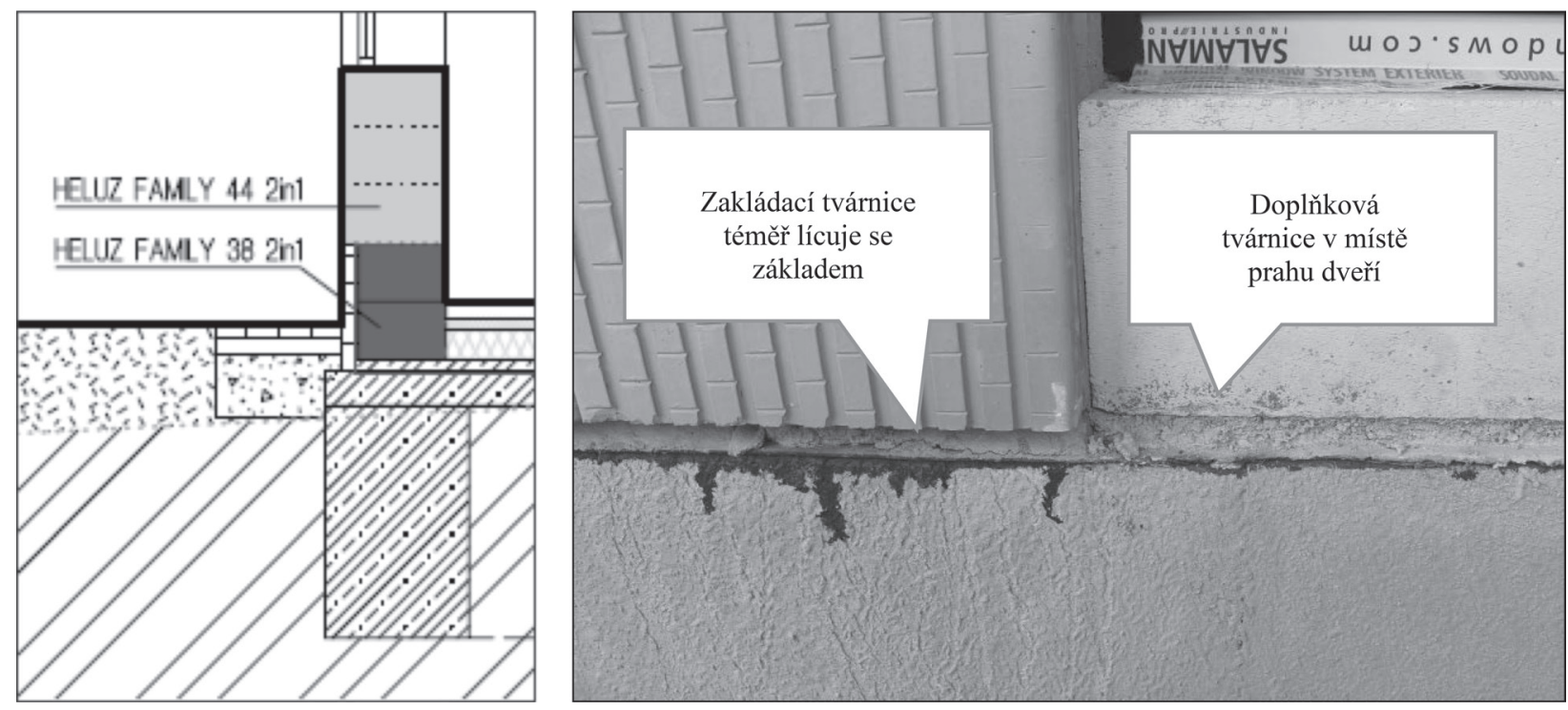

Obr. 1 Výřez z projektové dokumentace pro ohlášeni stavby, kde je uvedeno použití HELUZ FAMILY 38 2in1 pro prvni dvě rady zakládacího zdiva.

Fig. 1 Cut-out of the documents building notice, where HELUZ FAMILY $382 \mathrm{in} 1$ is used for the first two rows of foundation masonry. Obr. 2 Reálné provedení neodpovídá výkresu, zakládací řada téměr lícuje se základem.

Fig. 2 The real design does not correspond to the drawing, the foundation line is almost flush with the foundation.
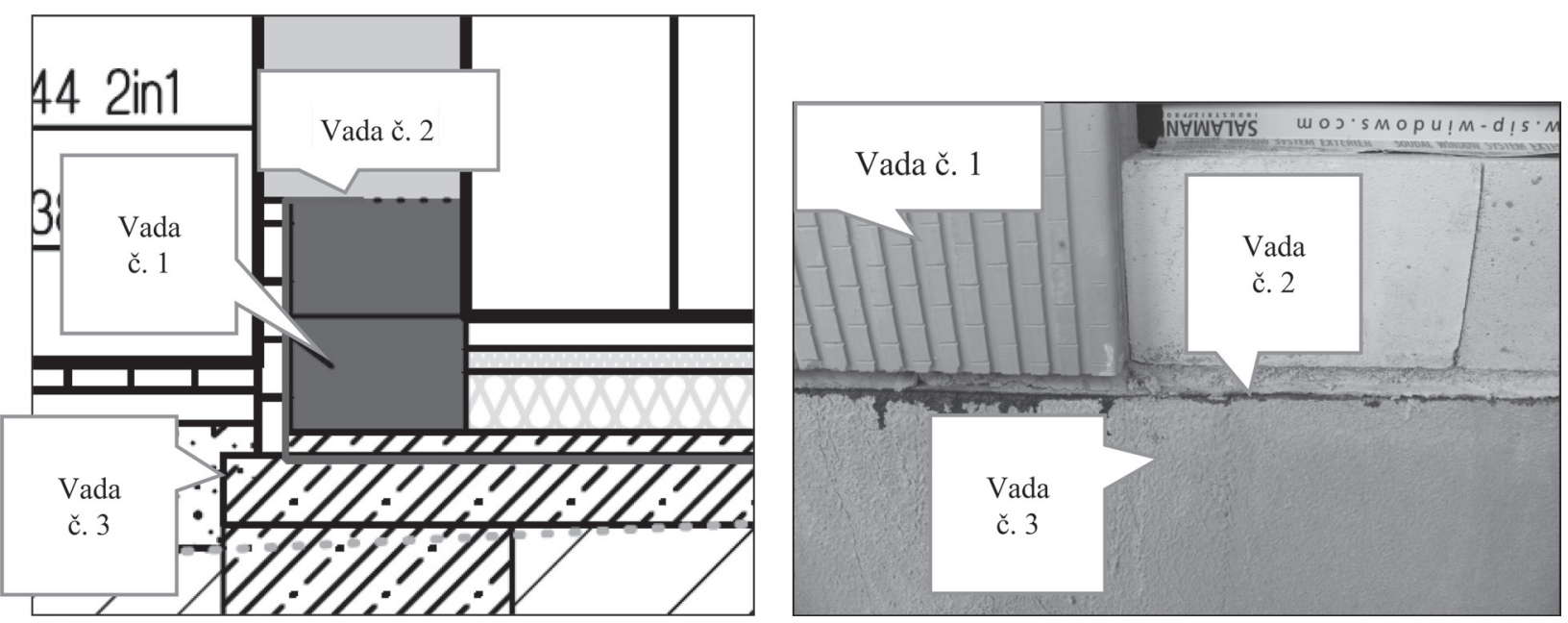

Obr. 3 a 4 Rozdíl mezi projektovaným stavem a realizovanými pracemi.

Fig. 3 and 4 Difference between projected state and realized work. 
a další změny, na jejichž základě nebudou moci být v budoucnu splněny podmínky ochrany stavby proti působení radonu, jak bylo předepsáno projektem. Dále na stavbě nebyl veden stavební deník, nebylo tedy možné změny v provedení zjistit jinak, než při místním šetření $\mathrm{v}$ době realizace stavby provedeného $\mathrm{z}$ důvodu ocenění objektu.

\subsubsection{Odchylka v provedeném založení}

Při místním šetření bylo zjištěno jiné provedení zakládací tvárnice oproti stavu uvedenému $\mathrm{v}$ projektové dokumentaci pro ohlášení stavby.

Byly zjištěny tyto dílčí vady:

\section{Vadné založení obvodového zdiva}

Pro založení měly být použity cihly menši šiřky, než je obvodové zdivo, aby bylo možné jejich zateplení a tím se předešlo vzniku tepelných mostů. Realizováno: Použití cihel stejných tlouštěk jako je tloušt'ka navazujícího obvodového zdiva.

\section{Vadné provedení hydroizolace}

Hydroizolace měla být zatažena až nad 2. řadu zakládacích cihel, kde měla být ukončena v ložné spáře. Realizováno: Hydroizolace byla ukončena pod 1. řadou zakládacích cihel. Napojení a navázání na takto zakončenou hydroizolaci je náročné a nákladné.

\section{Vadné provedení základů}

Základy byly dle PD zakresleny předstupující před obvodové zakládací zdivo. Realizováno: Základy téměř lícují s obvodovým zdivem, není možné provést zateplení zakládacích tvárnic takovým způsobem, aby lícovaly s navazujícím zdivem. Zateplením by se vytvořil předstupující sokl objektu.

\subsubsection{Použití jiného druhu cihel}

Při místním šetření bylo zjištěno použití jiných cihel, než bylo navrženo v projektu. Dle PD měly být použity cihly HELUZ FAMILY 44 2in1 a zakládací cihly HELUZ FAMILY 38 2in1. Při

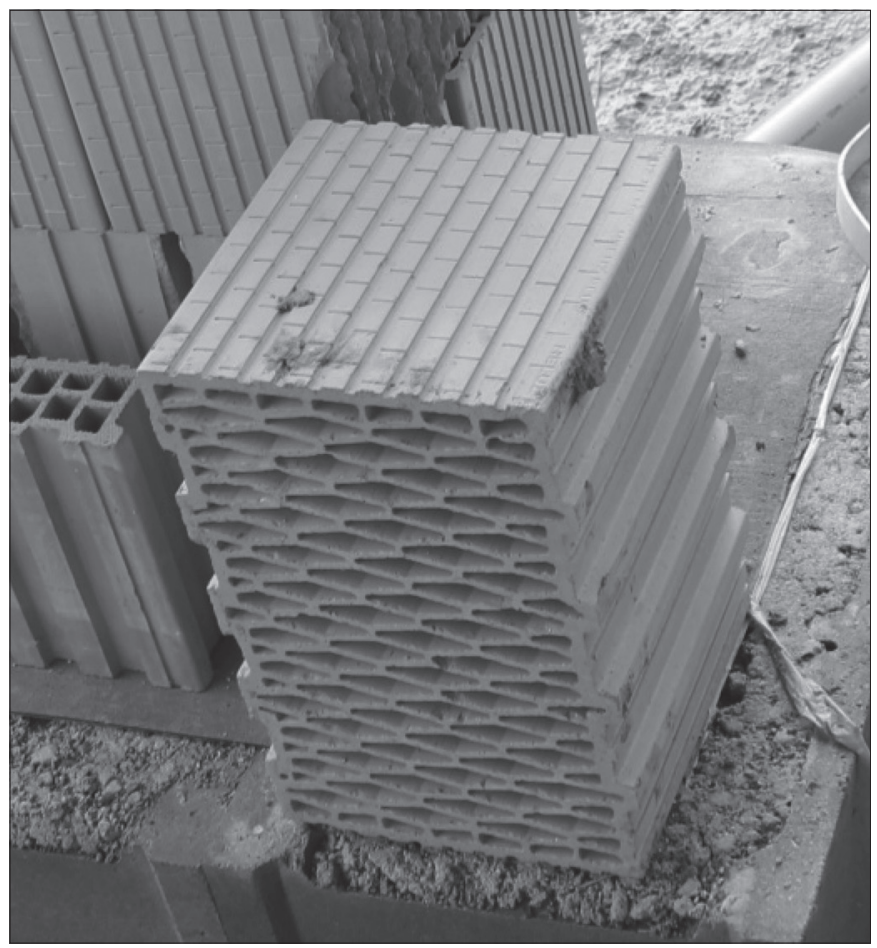

Obr. 5 Použité tvárnice pro stavbu rodinného domu. Fig. 5 Used blocks for building a house.

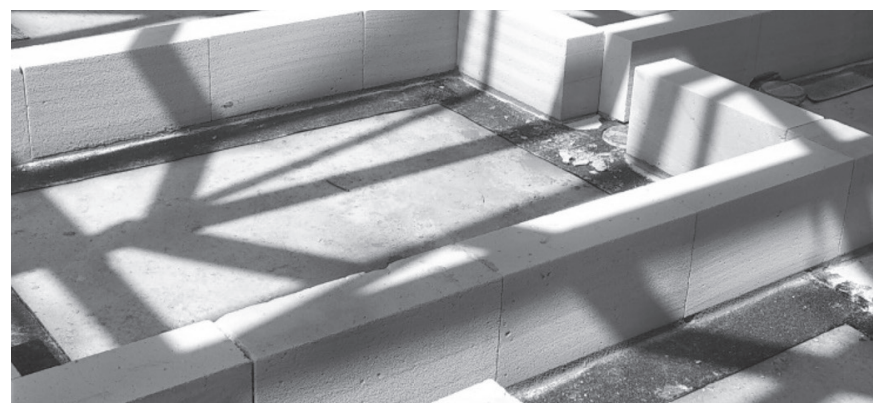

Obr. 6 Izolace pod príčkami. Izolace byla provedena pouze jako izolace proti zemni vlhkosti, chybi funkce izolace proti radonu.

Fig. 6 Insulation under partitions. The insulation was only used as insulation against earth moisture, the function of radon insulation is missing.
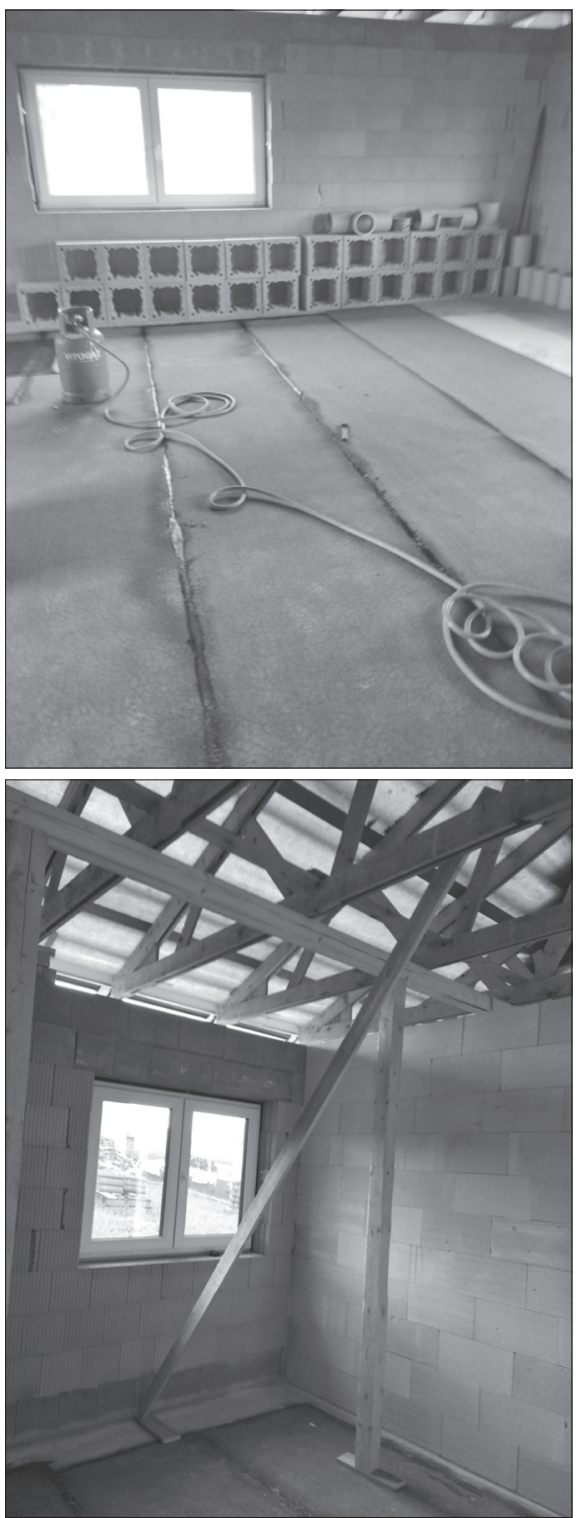

Obr. 7 a 8 Provedeni plošné izolace natavením. Jedná se o asfaltové pásy, jejich druh a typ nebyl bliže specifikován. Položené pásy neplní funkci ochrany proti puisobení radonu (radonový index pozemku je středni).

Fig. 7 and 8 Surface insulation by melting. These are bitumen belts, their type have not been specified. The laid belts do not fulfill the function of protecting against radon (the radon index of the plot is medium). 
místním šetření bylo zjištěno použití jiného typu cihel a to tvárnic bez vyplnění dutin polystyrénem.

Původně navržené cihly mají součinitel prostupu tepla $U=0,13$ $\mathrm{W} / \mathrm{m}^{2} \mathrm{~K}$, použité cihly jsou bez vyplnění dutin polystyrenem a mají až o $40 \%$ snížené tepelněizolační vlastnosti.

\subsubsection{Nebyla provedena radonová izolace, jak byla navržena v projektové dokumentaci}

V projektové dokumentaci bylo navrženo použití plastové hydroizolační fólie s ochranou proti radonu. Dle Protokolu o stanovení radonového indexu pozemku je radonový index pozemku střední a je nutno provést opatření proti vnikání radonu do objektu (obr. 6, 7, 8).

\subsubsection{Osazení do terénu neodpovídá projektové dokumentaci}

V projektové dokumentaci byl objekt osazen do terénu takovým způsobem, aby byly minimalizovány zemní práce a objekt nebyl př́liš zapuštěn do terénu kvůli nebezpečí stékání dešt’ové vody.
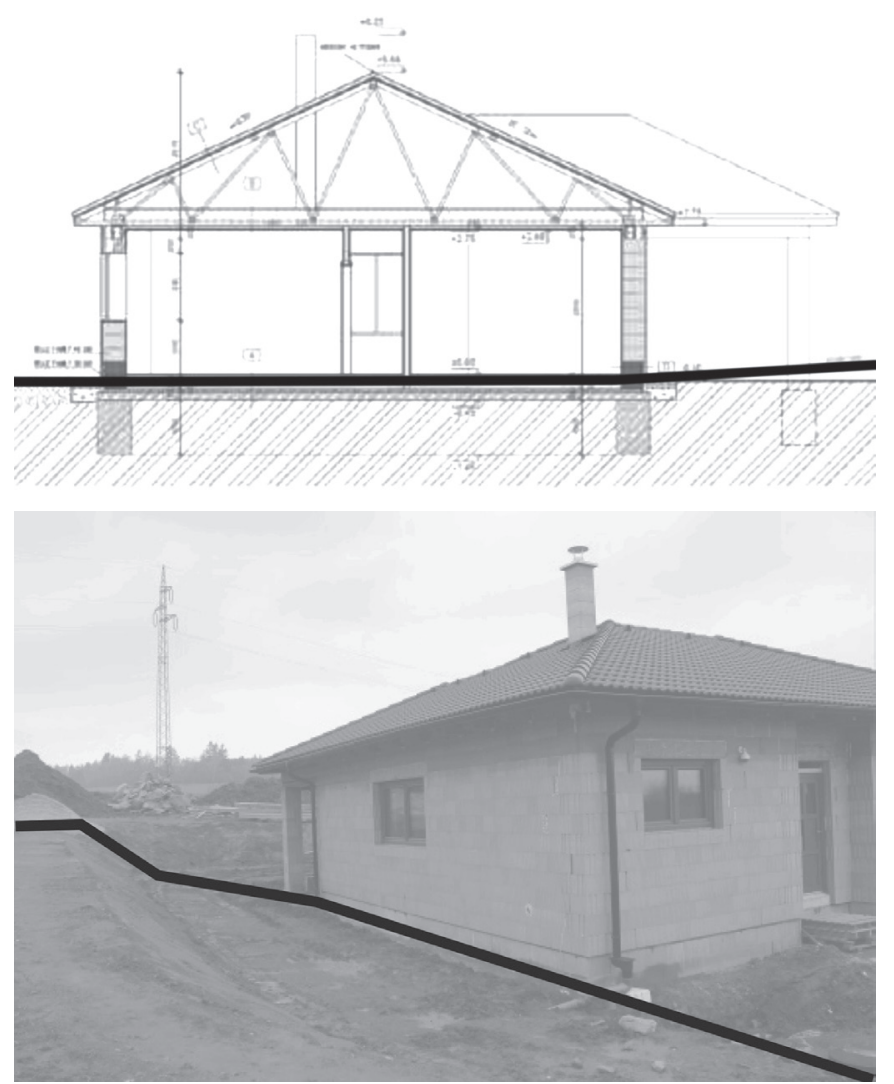

Obr. 9 a 10 Osazení objektu do terénu bylo navrženo s minimem zemnich prací. Reálné osazení do terénu bylo doprovázeno odebráním značné kubatury zeminy.

Fig. 9 and 10 Placing the building on the ground was designed with a minimum of earthwork. Real ground placement was accompanied by the removal of a large volume of soil.

\subsection{Př́́klad č. 2}

V př́íladu č. 2 je uvedeno nesprávné použití autorizačního razítka na výkresu skutečného provedení stavby. Hlavní rozpor mezi výkresovou dokumentací a skutečným stavem byl zjištěn zejména ve světlých výškách místností, kdy naměřené hodnoty

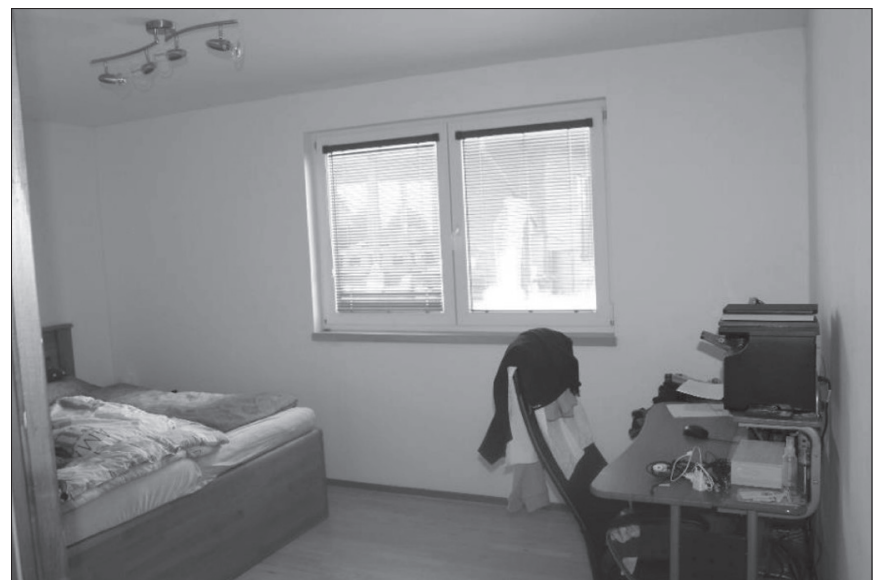

Obr. 11 Vadně provedená světlá výška místnosti pokoje 1. NP. Realizovaná světlá výška v mistnosti $2375 \mathrm{~mm}$ nevyhovuje minimální př́pustné světlé výšce 2500 mm dle vyhlášky č. 268/2009

Sb. Vyhláška o technických požadavcích na stavby,

$$
\text { \$ } 40 \text { císlo (2) [4]. }
$$

Fig. 11 Faintly made ground clearance of room of the 1 st floor. The realized ground clearance in the room of $2,375 \mathrm{~mm}$ does not comply with the minimum permissible height of 2,500 mm according to Decree No. 268/2009 Coll. Decree on technical requirements for construction, $\$ 40$ number (2) [4].

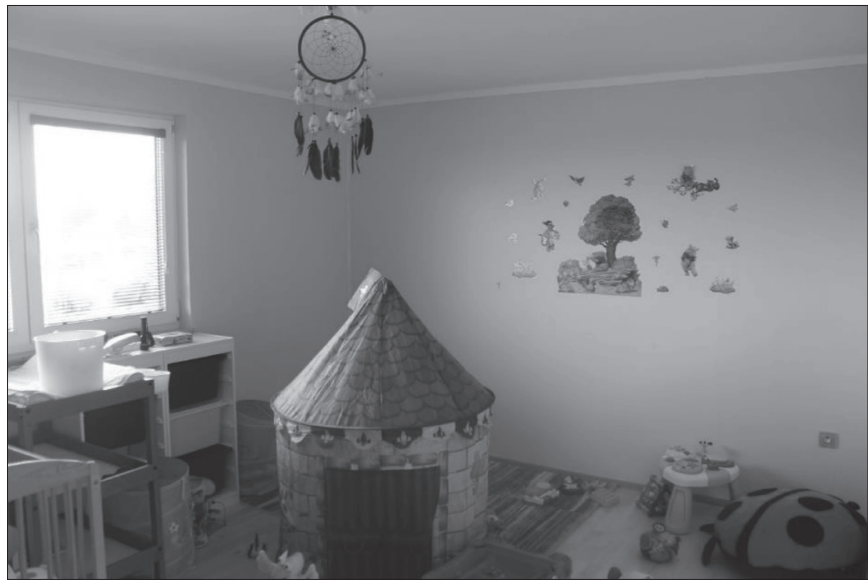

Obr. 12 V pokoji 1. NP byl proveden rovný podhled, světlá výška mistnosti byla změrena na $2382 \mathrm{~mm}$. Realizovaná světlá výška v mistnosti $2382 \mathrm{~mm}$ nevyhovuje minimálni prípustné světlé výšce 2500 mm dle vyhlášky č. 268/2009 Sb. Vyhláška o technických požadavcích na stavby, § 40 čislo (2) [4].

Fig. 12 A flat ceiling was made in the room of 1 st floor, the room height was measured at $2,382 \mathrm{~mm}$. The realized clearance height

in the room of 2,382 $\mathrm{mm}$ does not comply with the minimum permissible light height of 2,500 $\mathrm{mm}$ according to Decree No. 268/2009 Coll. Decree on technical requirements for construction, $\S$ 40 number (2) [4].

nesplňují podmínky uvedené ve vyhlášce č. 268/2009 Sb. Vyhláška o technických požadavcích na stavby [4], kdy rozdíly činily až $125 \mathrm{~mm}$ (obr. 11, 12, 13).

\subsection{Př́lklad č. 3}

Poslední z prríkladů ukazuje rozdílnost v provedení oproti projektové dokumentaci, která byla dokonce schválena i stavebním úřadem. Zásadním problémem bylo, že realizovaná vestavba půdního bytu 


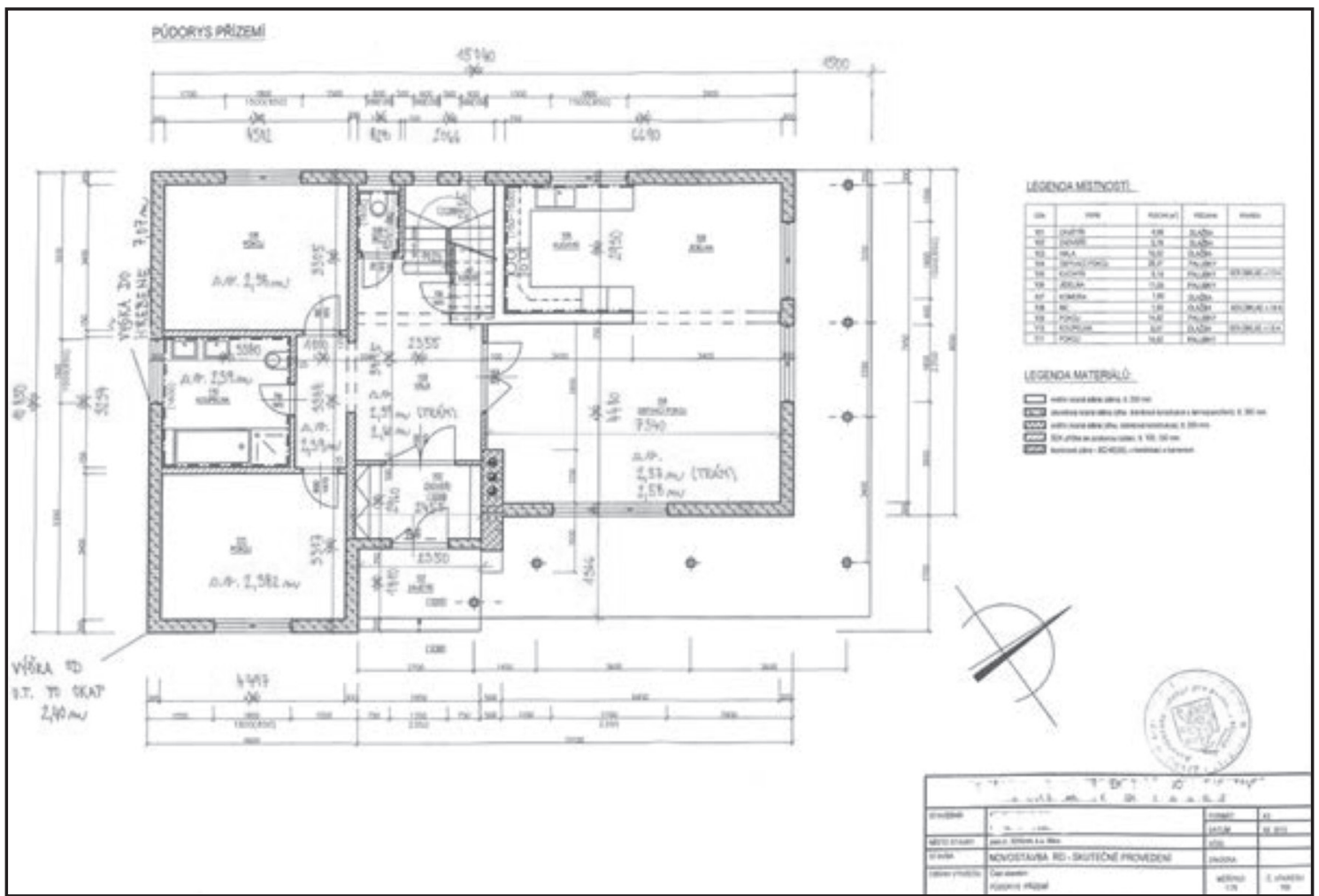

Obr. 13 Vyznačeny odchylky rozměrů stavby zjištěné změřním skutečného stavu v projektové dokumentaci, která byla označena jako „Skutečné provedeni“. Dokumentace je označena autorizačním razitkem (informace o autorovi jsou vymazány).

Fig. 13 The deviations of the dimensions of the building, as determined by measuring the actual state in the project documentation marked as "Actual execution“", are indicated. The documentation is marked with an authorization stamp (the author information is deleted).

se nacházela nad cizím pozemkem resp. stavbou. V tomto př́ípadě se jednalo o vadu projektové dokumentace a také o vadu v provedení.

Při vlastní realizaci zhotovitel provedl nadezdívku štítové zdi tak, že zdivo předsadil i přes původní nadezdívku sousedních domů (tloušt'ky $150 \mathrm{~mm}$ ) a provedl zateplení. Stavbyvedoucí zhotovitele pochybil, když realizoval přesah nadezdívky nad sousední domy, která činila cca $250 \mathrm{~mm}$. Touto stavební úpravou byl vyřešen požadavek na štítovou zed' z hlediska tepelné ochrany budov, ale za cenu toho, že došlo k předsazení štítové zdi nad sousední dům. Tato změna neměla být realizována. Souhlasy dotčených orgánů a osob se stavbou kontroluje př́slušný stavební úřad, který specifikuje, za jakých podmínek je možné stavbu realizovat.

Stavební povolení bylo vydáno na projektovou dokumentaci, která obsahovala vadu, když projekt dostatečným způsobem neřešil detail napojení posuzovaného bytu na sousední dům. Kolaudační souhlas byl vydán na realizované stavební úpravy tak, jak jsou v současné době majitelem bytu užívány. $Z$ vydaného stavebního povolení a z kolaudačního souhlasu lze vyvozovat, že pracovník stavebního úřadu nezjistil žádné pochybení, které by bránilo povolení stavby $\mathrm{k}$ realizaci a následně k užívání bytu.
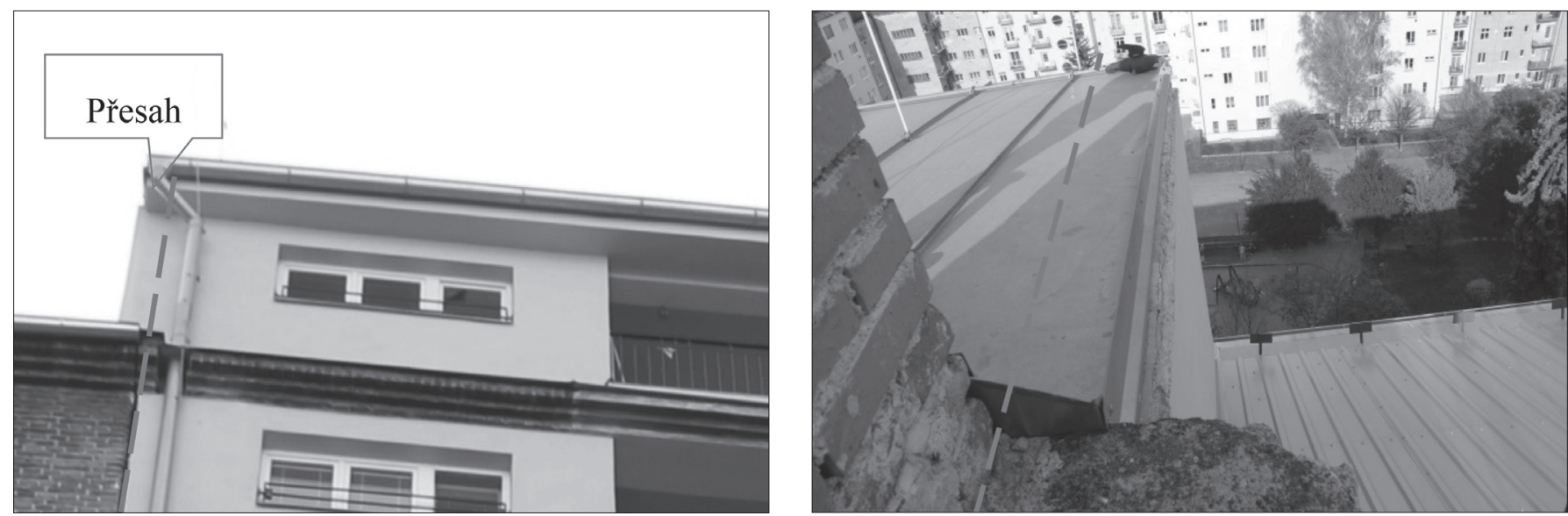

Obr. 14 a 15 Vyznačení přesahu předmètné bytové jednotky a vyznačená část přesahu.

Fig. 14 and 15 The overlap of the housing unit and the marked part of the overlap. 


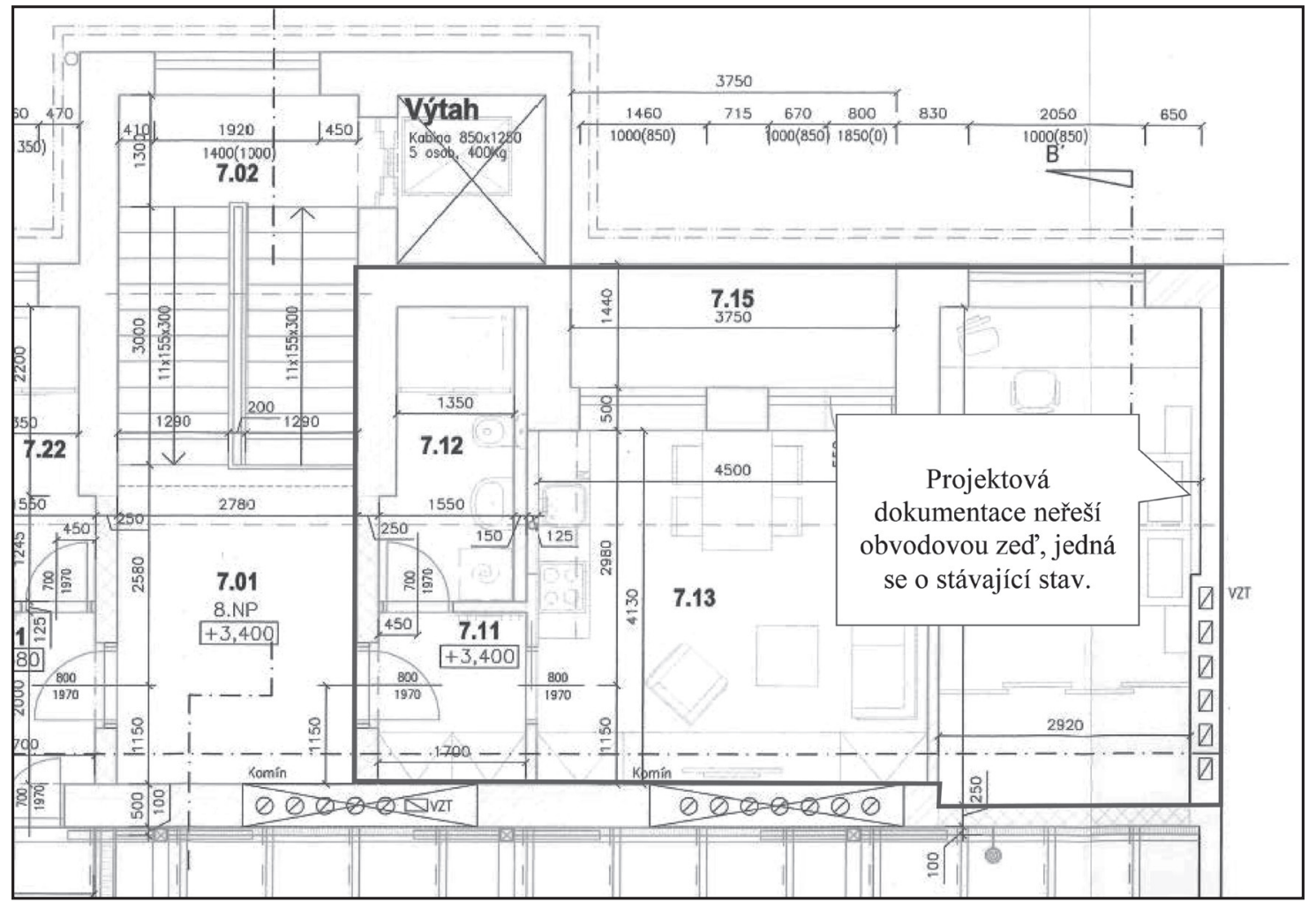

Obr. 16 V projektové dokumentaci nebyly řešeny požadavky na tepelnou ochranu, byla nakreslena stávající zed’.

Fig. 16 The thermal protection requirements were not addressed in the project documentation, the existing wall was drawn.

Zástupce sousedního bytového domu měl možnost vyjádřit se před vydáním stavebního povolení k zamýšleným stavebním úpravám a v průběhu realizace upozornit na vadný postup zhotovitele, stejně tak stavebník. Jedná se však o účastníky a stavebníka, kteří nemají pravděpodobně dostatečné odborné znalosti.

\section{ZÁVĚR}

Na uvedených př́kladech chtěli autoři tohoto článku upozornit, že ve stavební praxi může docházet a dochází během výstavby objektů ke změnám, které se nemusí dostat do výkresové dokumentace.

Ani označení projektové dokumentace autorizačním razítkem není zárukou shody s realitou, často pak dochází $\mathrm{k}$ použití autorizačního razítka i v př́padech, kdy se toto nevyžaduje. $\mathrm{Z}$ těchto důvodů by měly informace, které budou použity pro ocenění objektu, vycházet hlavně z osobní prohlídky objektu, ale ani tak není možné zjistit řadu úprav a změn provedených při výstavbě, protože se často jedná o zakryté práce, kdy je pro zjištění skutečného stavu potřebné provedení sondy, popřípadě použití účinné nedestruktivní metody pro jeho zjištění.

Největším problémem pak je dodržování stavebního zákona a zákona o autorizaci [5] v oblasti př́ípravy a projektování staveb, ale především při realizaci staveb. Situaci ve stavebnictví nám charakterizuje i stav umístění naší republiky v povolování staveb, kdy se dle dostupných informací řadíme ze 190 států na 156 . místo [6].

\section{LITERATURA}

[1] Zákon č. 183/2006 Sb.: Zákon o územním plánování a stavebním řádu (stavební zákon). In: Praha, 2006, číslo 183.

[2] Česká komora autorizovaných inženýrů a techniků činných ve výstavbě: Pravidla pro používání razítka při výkonu povolání autorizovaného inženýra a autorizovaného technika [online]. Praha, b.r. [cit. 2019-01-06]. Dostupné z: http://www.ckait.cz/ content/pouziti-autorizacniho-razitka-0

[3] Vyhláška č. 499/2006 Sb.: Vyhláška o dokumentaci staveb.

[4] Vyhláška č. 268/2009 Sb.: Vyhláška o technických požadavcích na stavby.

[5] Zákon č. 360/1992 Sb.: Zákon České národní rady o výkonu povolání autorizovaných architektů a o výkonu povolání autorizovaných inženýrů a techniků činných ve výstavbě.

[6] Internetový článek: Česko patří v povolování staveb mezi nejhorší na světě. Změníme to?, dostupný z: https://www. parlamentnilisty.cz/profily/Ing-Martin-Kolovratnik-32354/ clanek/Cesko-patri-v-povolovani-staveb-mezi-nejhorsi-na-sveteZmenime-to-90747, el. článek z 4. 12. 2018

[7] Sbornik přsspěvků, ExFoS 2019. ISBN: 978-80-214-5708-9.

\section{Správná citace:}

Ledvoňová, M., Pejchal, P. Rozpor mezi projektovou dokumentací a skutečným stavem vztaženo k problematice oceňování objektů. Soudní inženýrství, 2019, 30(2), 25-31. DOI: http://dx.doi.org./10.13164/SI.2019.2.25. ISSN 1211-443X. 